Jerzy Janczewski* (1) https://orcid.org/0000-0002-6994-2683 e-mail: jerzyjanczewski@poczta.onet.pl

Danuta Janczewska * (D) https://orcid.org/0000-0003-1013-5665 e-mail: janczewska@republika.pl

\title{
Mikromobilność z perspektywy rozwoju rowerów, hulajnóg i mikrosamochodów. Ujęcie retrospektywne
}

https://doi.org/10.25312/2391-5129.30/2020_12jjdj

\begin{abstract}
Mikromobilność nie posiada jednoznacznej definicji. Niekiedy formułowana jest dla konkretnych warunków, a jej zakres dotyczy potrzeb badaczy lub zainteresowanych instytucji. Mikromobilność w transporcie była obecna od dawna, choć w epoce intensywnego rozwoju motoryzacji na świecie była marginalizowana na korzyść wszechobecnego kultu samochodu.

Przejawy mikromobilności można odnieść do przypadków powstania i rozwoju urządzeń powolnego transportu, między innymi takich jak rowery, hulajnogi oraz mikrosamochody. Początki takich urządzeń sięgają niespełna 200 lat. Najpierw były one napędzane siłą mięśni użytkownika, a następnie, po wynalezieniu i udoskonaleniu jednostek napędowych, otrzymywały napęd mechaniczny, a także elektryczny. Na ich podstawie powstawały kolejne konstrukcje, stale udoskonalane i modernizowane.

Artykuł ma na celu przegląd powstania i rozwoju trzech najważniejszych zdaniem autora środków transportowych mikromobilności: rowerów, hulajnóg i mikrosamochodów, i tym samym uzasadnienie tezy, że mikromobilność należy postrzegać nie tylko przez pryzmat usługi, ale też z perspektywy ewolucji jej środków transportu.
\end{abstract}

Słowa kluczowe: mikromobilność, rower, hulajnoga, mikrosamochód

* Dr inż. Jerzy Janczewski - adiunkt w Katedrze Systemów Transportu na Wydziale Informatyki, Zarządzania i Transportu Akademii Humanistyczno-Ekonomicznej w Łodzi.

** Dr inż. Danuta Janczewska - adiunkt, Społeczna Akademia Nauk w Łodzi. 


\section{Wstęp}

Pojęcie mikromobilności nie posiada jednoznacznej definicji. Niekiedy formułowana jest ona dla konkretnych warunków, a jej zakres dotyczy potrzeb badaczy lub zainteresowanych instytucji. Mikromobilność w transporcie była obecna od dawna, choć w epoce intensywnego rozwoju motoryzacji na świecie była marginalizowana na korzyść wszechobecnego kultu samochodu.

Można przyjąć, że mikromobilność to koncepcja zakładająca wykorzystanie w rozwiązaniach transportowych niewielkich, lekkich i bezemisyjnych pojazdów silnikowych oraz urządzeń powolnego transportu umożliwiających pokonywanie krótkich dystansów - najczęściej pierwszego lub ostatniego odcinka zaplanowanej podróży. Dzięki niewielkim gabarytom i małej masie transportowe środki mikromobilności ułatwiają poruszanie się po wąskich i zatłoczonych odcinkach miast, a ich alternatywny napęd eliminuje hałas i redukuje tzw. ślad węglowy. Zaliczają się do nich między innymi rowery, hulajnogi, deskorolki i tym podobne urządzenia transportu osobistego (UTO), skutery i motorowery, a także małe, lekkie samochody (Janczewski, 2020: 258-259).

Przejawy mikromobilności należy odnieść do przypadków powstania i rozwoju urządzeń powolnego transportu między innymi takich jak rowery, hulajnogi oraz mikrosamochody. Początki takich urządzeń sięgają niespełna 200 lat. Najpierw były one napędzane siłą mięśni użytkownika, a następnie, po wynalezieniu i udoskonaleniu jednostek napędowych, otrzymywały napęd mechaniczny, a także elektryczny. $\mathrm{Na}$ ich podstawie powstawały kolejne konstrukcje, stale udoskonalane i modernizowane. W licznej grupie tych pojazdów i w ich bogatej historii powstania i rozwoju można odnaleźć pewne charakterystyczne cechy, takie jak: rodzaj napędu i rodzaj nośnika energii, masa własna i dopuszczalna masa całkowita, zasięg, prędkość maksymalna, dostęp do infrastruktury.

Artykuł ma na celu przegląd powstania i rozwoju trzech zdaniem autora najważniejszych środków transportowych mikromobilności, a mianowicie rowerów, hulajnóg i mikrosamochodów, i tym samym uzasadnienie tezy, że mikromobilność należy postrzegać nie tylko przez pryzmat usługi, lecz również z perspektywy ewolucji jej środków transportu.

\section{Rower}

Pierwsze historycznie udokumentowane wydarzenie związane z rowerem pochodzi z 12 lipca 1817 roku, kiedy Karl Drais von Sauerbronn przedstawił jednośladowy pojazd dwukołowy, który napędzał siedzący na nim człowiek, odpychając się stopami od ziemi' ${ }^{1}$ Był to pierwowzór roweru, zwany maszyną do biegania (niem. Laufs-

${ }^{1}$ Nie oznacza to jednak, że pojazdy podobne do roweru nie mogły być znane i wykorzystywane dużo wcześniej (zob. Historia roweru, 2020). 
machine) lub od nazwiska konstruktora nazywany drezyną. Posiadał on obrotową kierownicę, później stalowe okucia na kołach, skórzane siodło z regulacją wysokości, hamulec działający na tylne koło, licznik odległości i umożliwiał podróżowanie z prędkością 10-15 km/h (rys. 1). Po wykazaniu swojej użyteczności otrzymał on 12 stycznia 1818 roku badeński przywilej do wynalazku, czyli dzisiejszy patent. Należy też nadmienić, że cztery lata wcześniej ten sam wynalazca złożył pierwszy wniosek patentowy dotyczący czterokołowego wozu, napędzanego przez siedzących w nim ludzi, zwanego drezyną, a w 1814 roku zaprezentował pojazd w Wiedniu. Na powstanie tych wynalazków w dużej mierze wpłynął fakt, że w tym czasie transport konny był drogi. W konsekwencji wynalezione pojazdy zyskały dużą popularność, zwłaszcza we Francji i Anglii. Później, gdy transport konny stał się tańszy, straciły na znaczeniu (Penkała, 2020).

W 1839 roku Szkot Kirkpatrick MacMillan opracował pojazd z mechanizmem napędowym, dzięki czemu nie było potrzeby odpychania się od ziemi podczas jazdy. Mechanizm skonstruowany był z dwóch pionowych prętów, przymocowanych wahliwie do kierownicy, połączonych przyczepionymi przegubowo prętami z korbami osadzonymi na piaście tylnego koła (rys. 2). Pojazd był wprawiany w ruch poprzez naprzemienne ruchy nogami do przodu i do tył. W 1842 roku MacMillan przejechał tym pojazdem liczącą $229 \mathrm{~km}$ trasę z Courthill do Glasgow i z powrotem, na której osiągnął średnią prędkość około $13 \mathrm{~km} / \mathrm{h}$. Właściciel tego wynalazku był również sprawcą pierwszego odnotowanego wypadku rowerowego, gdyż na swoim pojeździe potrącił dziecko, za co został ukarany karą grzywny. Wynalazek MacMillana nie zyskał jednak większej popularności.

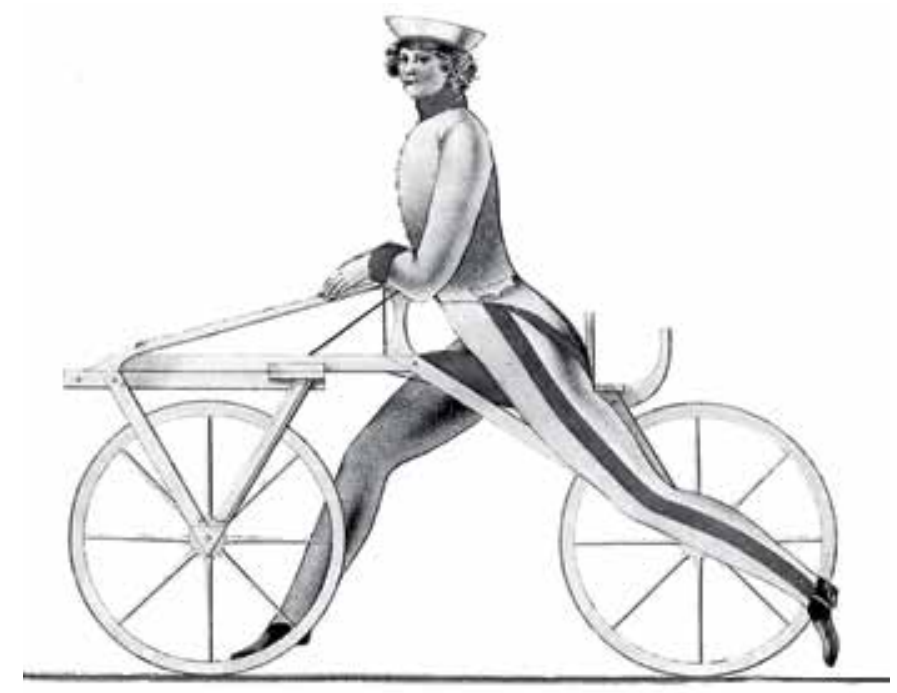

Rysunek 1. Maszyna do biegania według konstrukcji Karla Draisa von Sauerbronna Źródło: Wikimedia Commons, 2020a. 


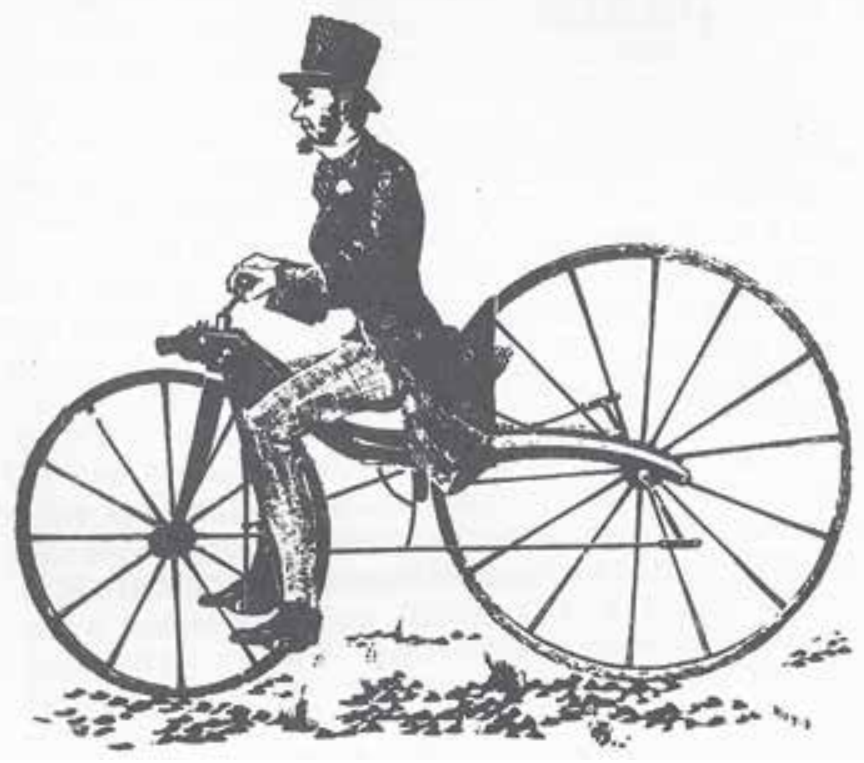

Rysunek 2. Rower z mechanizmem napędowym według konstrukcji MacMillana Źródło: Wikimedia Commons, 2020b.

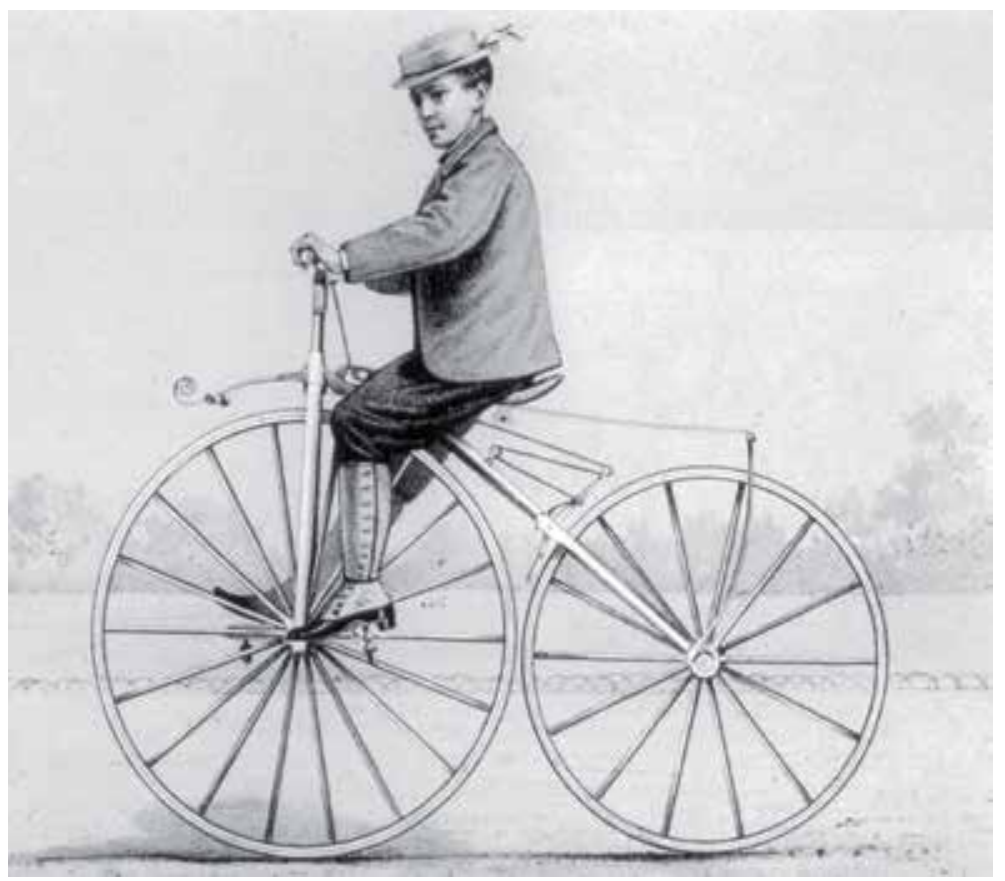

Rysunek 3. Rower z mechanizmem napędowym według konstrukcji Pierre’a Michaux Źródło: Wikimedia Commons, 2020c. 


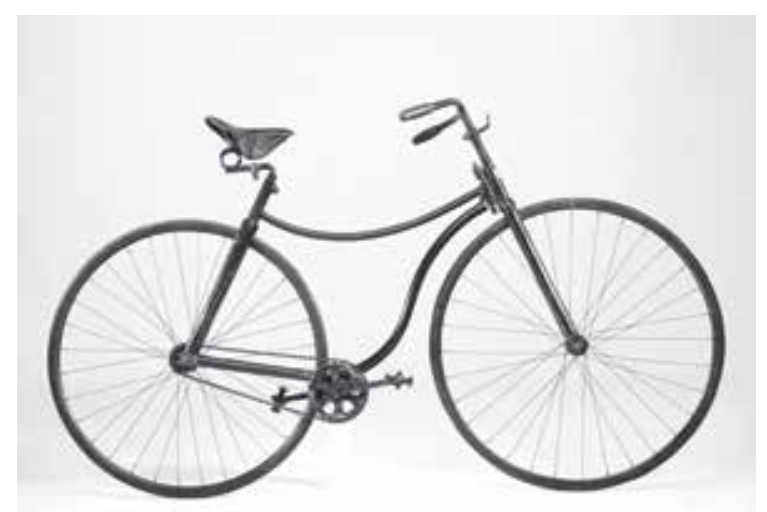

Rysunek 4. Rower z łańcuchowym mechanizmem napędzającym tylne koło Źródło: Rover 'Safety' bicycle, 1885.

Mechanizm napędowy w rowerze, którego zasada działania stosowana jest do dnia dzisiejszego, skonstruowali w 1862 roku dwaj Francuzi: Pierre Michaux i jego syn Ernest. Wprowadzili oni do konstrukcji roweru obrotowe pedały, które były przymocowane bezpośrednio do osi przedniego koła (zainspirowani prawdopodobnie kołem szlifierskim) (rys. 3). Rower Francuzów był drewniany, ważył około $50 \mathrm{~kg}$ (w późniejszych konstrukcjach zredukowano masę o połowę) i posiadał przednie koło nieco większe od tylnego. Pojazd rozwijał prędkość około $10 \mathrm{~km} / \mathrm{h}$. Pierre Michaux otworzył sklep i fabrykę, w której wytwarzał trzy do pięciu pojazdów dziennie, stopniowo udoskonalając je. Wprowadził na przykład obręcze zdolne utrzymać oponę z pełnej gumy, dzięki czemu jazda jest trochę wygodniejsza, czy siodełko ze stalowymi sprężynami.

Pierwsze rowery były niewygodne i niebezpieczne, trudne do kierowania, nie zapewniały też należytej stabilności. Rozwiązaniem okazały się: łańcuch i przekładnia, dzięki której koła mogły zachowywać określoną wielkość. Wykorzystał to w 1885 roku John Kemp Starley, konstruując pojazd, który nazwał Rover Safety Cycle. Stał się on pierwowzorem dzisiejszych rowerów z bezpośrednio skręcaną kierownicą, kołami równej wielkości i czworoboczną ramą (rys. 4). Jazda takim pojazdem była łatwiejsza, bezpieczniejsza i przyjemniejsza.

Od lat dziewięćdziesiątych XIX wieku zasadnicza idea roweru nie uległa zmianie, wprowadzono wiele poprawek konstrukcyjnych: mocniejsze i lżejsze ramy, doskonalsze przekładnie i hamulce czy inne umiejscowienie siodełka. Jak większość urządzeń służących człowiekowi, rower podlegał nieustannym modernizacjom; poszukiwano jak najlepszych rozwiązań, aby jeździło się coraz wygodniej (Historia roweru, 2020).

Rower na przestrzeni wieków zyskał wiele zastosowań i stale cieszy się bardzo dużą popularnością. Zauważa się także rosnące zainteresowanie rozwiązaniami, w których do napędu oprócz tradycyjnych pedałów uruchamianych siłą ludzkich mięśni wykorzystuje się dodatkowy napęd, na przykład silnik elektryczny. 
Historia roweru z dodatkowym napędem sięga wielu lat wstecz (około 150). Od czasu wprowadzenia pierwszych rowerów próbowano przekształcić je w urządzenia napędzane silnikiem, początkowo nawet parowym - gdyż tylko taki był wtedy dostępny (zob. S.H. Roper and his steam-engine powered velocipedes, 2020). Rowery z silnikami elektrycznymi pojawiły się pod koniec XIX wieku. Pierwszym pomysłodawcą silnika elektrycznego w piaście tylnego koła był w 1895 roku Ogden Bolton (zob. Ogden Bolton J.R. and his 1895 hub motor ebike, 2020). Największym problemem tego czasu były zasobniki energii. Baterie miały duże rozmiary i były bardzo ciężkie w porównaniu z tymi, których używa się obecnie. Wymownym przykładem elektrycznego roweru z końca XVIII wieku jest rower tandem wykorzystany w 1899 roku do nadania tempa wyścigom kolarskim w Paryżu (rys. 5). Rower był bardzo ciężki, gdyż posiadał 4 akumulatory i nie mógł konkurować z lżejszym napędem spalinowym. Do 1904 roku wyprodukowano tylko kilka jego egzemplarzy i z braku zainteresowania rynku produkcję przerwano (zob. Desmond, 2019: 34-36; Cybermotorcycle.com, 2020).

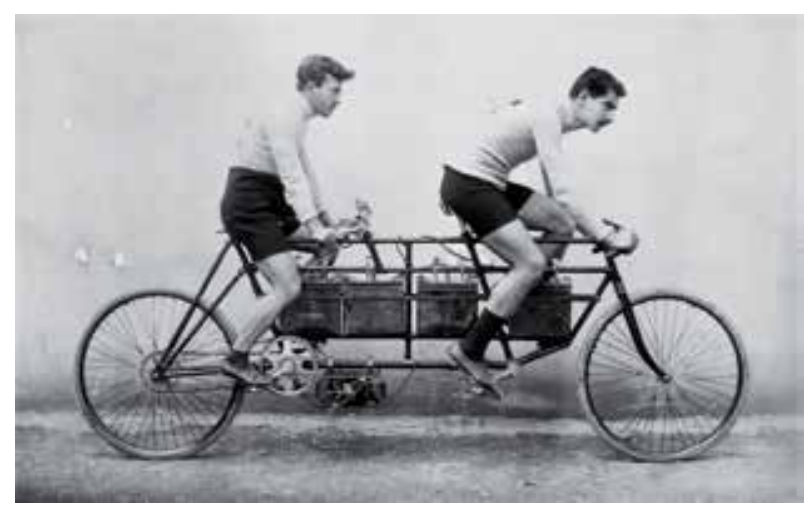

Rysunek 5. Elektryczny tandem Humbera

Źródło: Cybermotorcycle.com.

W latach trzydziestych XX wieku rowery elektryczne znalazły się w obszarze zainteresowania kilku firm europejskich. Dostępna w tamtych czasach technologia zasobników energii elektrycznej nadal nie pozwalała na produkowanie lekkich pojazdów o dużym zasięgu, więc oczekiwano, że e-rowery uzupełnią lukę między tradycyjnymi rowerami a motorowerami i motocyklami z silnikiem spalinowym. Mimo zaangażowania w produkcję takich firm, jak Philips i Gazelle nie udało się masowo wyprodukować i rozpowszechnić elektrycznych rowerów. Sprzedano tylko 117 takich rowerów (rys. 6). Nadal miały one stosunkowo dużą masę, ich prędkość eksploatacyjna wynosiła $18 \mathrm{~km} / \mathrm{h}$, zasięg około $40 \mathrm{~km}$, zaś akumulator wymagał długiego czasu ładowania (cały dzień) (Electric bikes during the thirties, 2020).

Przez większą część XX wieku zainteresowanie rowerem z napędem elektrycznym było niewielkie. Sporadycznie stosowano do rowerów małe przyczepne silniki 
spalinowe. Ropa naftowa była powszechnie dostępna i tania, a świadomość ekologiczna społeczeństw niewielka. Era masowej motoryzacji skutkująca przyrostem liczby samochodów i motocykli spowodowała, że tylko osoby, których nie było stać nawet na najtańszy samochód, nadal korzystały z rowerów.

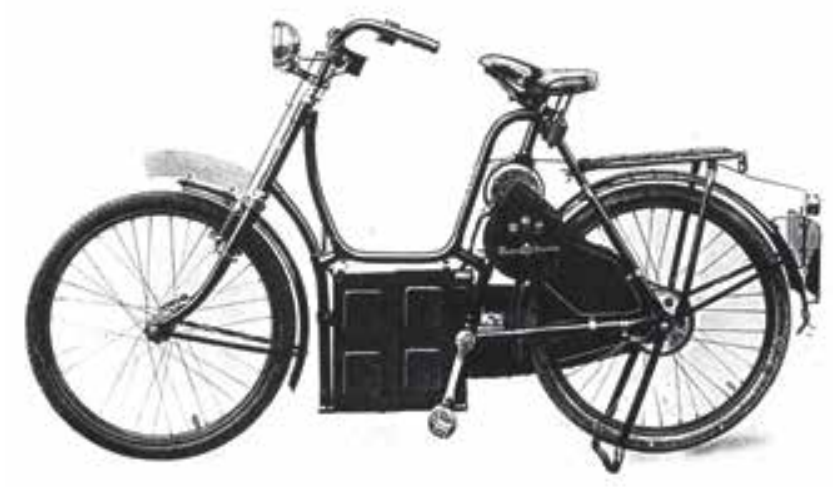

Rysunek 6. Elektryczny rower na licencji Philipsa wyprodukowany przez holenderską firmę Burgers

Źródło: Burgers E.N.R.

Kryzys naftowy w 1973 roku i pierwsze przejawy dbałości o naturalne środowisko spowodowały ponowne zainteresowanie rowerami elektrycznymi, jednak nawyk korzystania z samochodu nie pozwalał na ich rozpowszechnienie. Obecnie notuje się odwrotny trend, gdyż zmiany technologiczne dostarczyły lekkie i pojemne baterie małych rozmiarów, a e-rowery mogą swobodnie zastępować samochody podczas podróży na niewielkich odległościach, uciążliwych do pokonania pieszo lub tradycyjnym rowerem. W ciągu ostatnich kilku lat rynek e-rowerów cechuje wysoka dynamika wzrostu. Producenci oferują nowe rozwiązania, aby zapewnić funkcjonalny i coraz doskonalszy produkt (History of ebikes, 2020) (rys. 7).

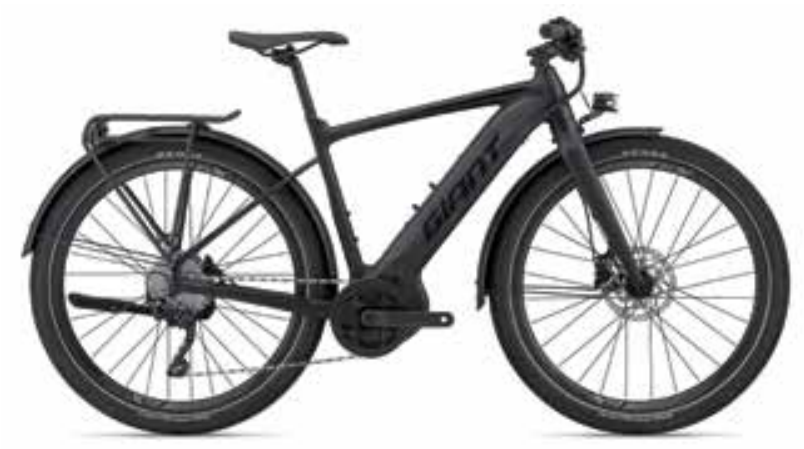

Rysunek 7. Przykład współczesnego roweru elektrycznego Źródło: Green Bike. Rowery elektryczne, 2020. 


\section{Hulajnoga}

Hulajnogi mogą mieć dwa, trzy lub cztery koła, a także dodatkowy napęd. Zazwyczaj przeznaczone są dla jednej osoby. Najprostsza hulajnoga składa się z płaskiej, wąskiej platformy, na której końcach umieszczone są koła jezdne. Do przedniego koła umocowana jest kierownica. Użytkownik hulajnogi stoi na platformie, odpychając się jedną nogą od podłoża, i kieruje pojazdem za pomocą kierownicy.

W literaturze przedmiotu brakuje jednoznacznych informacji, kto wynalazł pierwszą hulajnogę. Najprawdopodobniej wywodzi się ona z konstrukcji roweru biegowego, ale mogło być też odwrotnie. Być może pomysł roweru biegowego nasunął się dopiero po wynalezieniu hulajnogi, kiedy okazało się, że podróżowanie w pozycji siedzącej jest mniej uciążliwe niż w pozycji stojącej i dodatkowo do napędu można wykorzystać obie nogi, a nie jedną tak jak w przypadku hulajnogi.

Niektóre źródła sugerują, że pierwsza hulajnoga została skonstruowana w 1817 roku w Niemczech, a w Stanach Zjednoczonych pojawiła się w czasach Wielkiego Kryzysu, gdy dzieci budowały ją sobie same jako zabawkę z odzyskanego drewna (zob. Wikimedia Commons, 2020a). Podobne hulajnogi rozpowszechniano w Polsce w czasach wczesnego PRL-u (rys. 8).

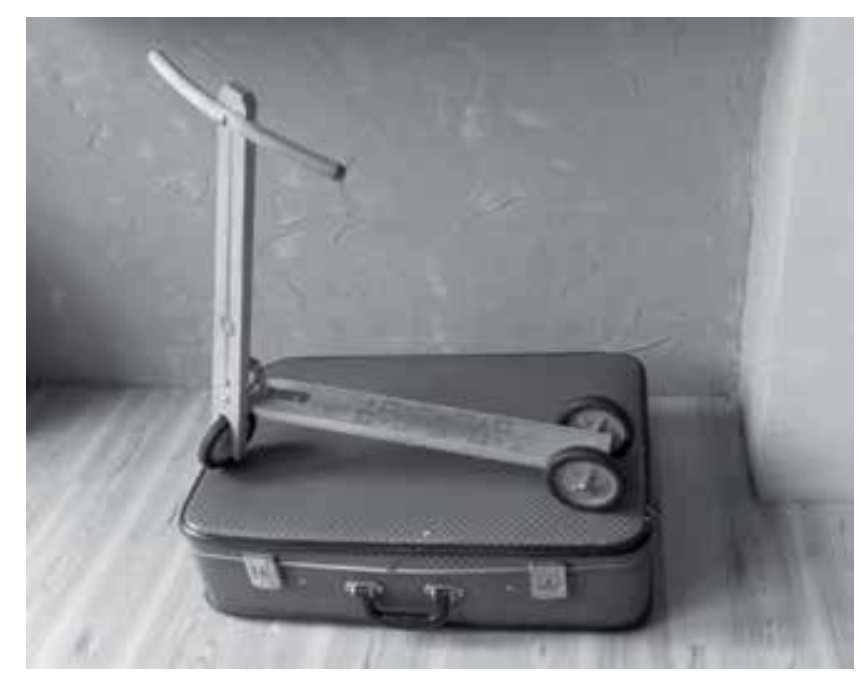

Rysunek 8. Przykładowa drewniana hulajnoga, PRL

Źródło: Pinterest, 2020.

Inne źródła podają, że pierwszą hulajnogę wynalazł w 1897 roku Walter Lines z Wielkiej Brytanii, ale nie był on świadomy potrzeby i procesu jej patentowania (Hulajnoga, 2020). Pewne skojarzenia $\mathrm{z}$ hulajnogą, na przykład z powodu niskiej płyty, wywołuje pojazd o dużych kołach (rys. 9), wyprodukowany w 1819 roku przez Denisa Johnsona (zob. Denis Johnson (inventor), 2020). Pojazd ten mógłby pełnić 
funkcje roweru biegowego oraz hulajnogi i być może stał się inspiracją dla dużych hulajnóg o stalowej ramie z małym tylnym kołem i o wiele większym kołem przednim. Hulajnogi takie były popularne w Finlandii i w wielu innych krajach, a niektóre z nich są nadal używane w zatłoczonych obszarach miejskich, ponieważ są szybsze niż typowa hulajnoga $\mathrm{z}$ małymi kołami i wygodniejsze niż tradycyjny rower (rys. 10). Niektóre z nich są przeznaczone do użytku w terenie i nazywane górskimi. Oprócz dojazdów do pracy, zawodów sportowych i jazdy w terenie duże hulajnogi są stosowane w zaprzęgach psów, analogicznie do sanek.

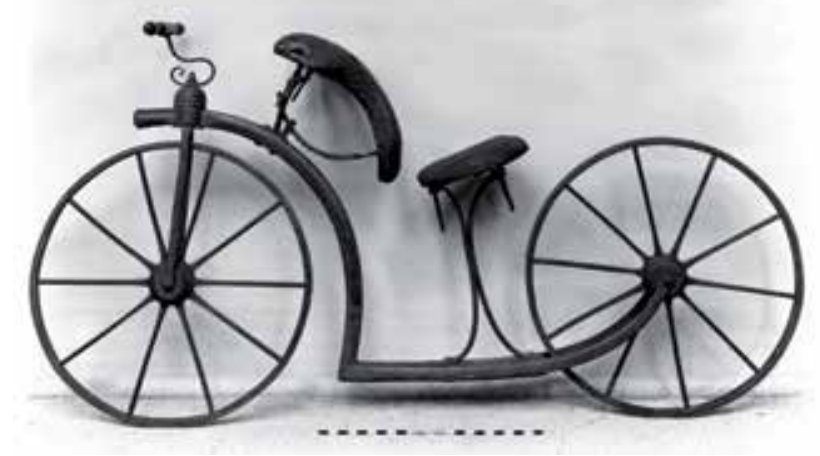

Rysunek 9. Pojazd wyprodukowany przez Denisa Johnsona Źródło: Wikimedia Commons, 2020d.

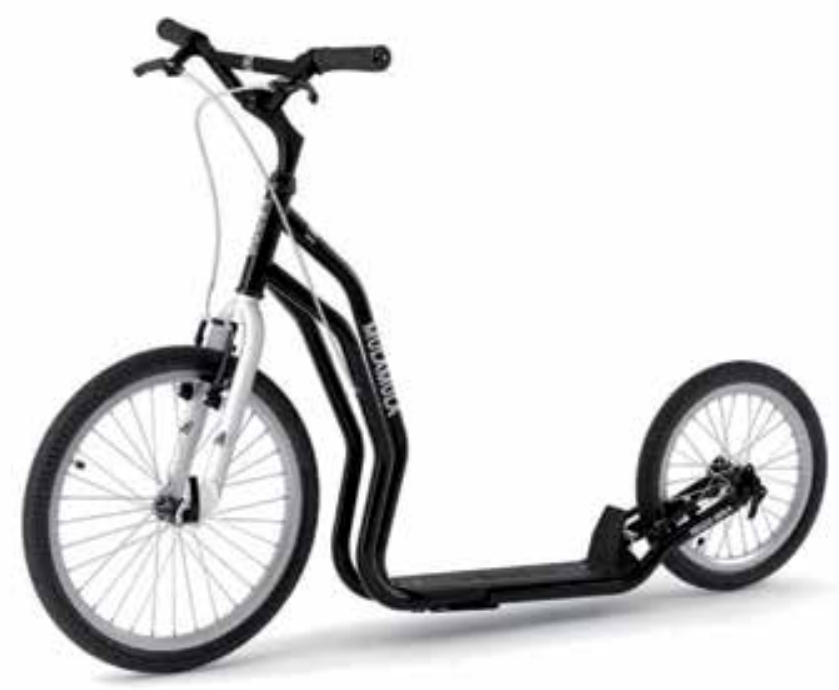

Rysunek 10. Przykład współczesnej hulajnogi Źródło: Google.com. 
W latach pięćdziesiątych XX wieku hulajnoga stała się bardzo popularna, jednak później została wyparta przez deskorolki. W 1974 roku firma Honda wyprodukowała Kick N Go, hulajnogę, której tylne koło było bezpośrednio napędzane przez użytkownika pedałem sprzęgniętym z systemem dźwigni (zob. Mitchell, 2015; Honda Kick N Go 2, 2020). Chociaż rozpoczęcie jazdy łączyło się z dużym wysiłkiem, gdyż wymagało pokonania zwiększonych oporów toczenia, a także oporów samego mechanizmu, to nowość została przez użytkowników zaakceptowana i pojazd zyskał dużą popularność.

W 1996 roku Wim Ouboter, właściciel firmy Micro Mobility Systems w Szwajcarii, stworzył składaną hulajnogę (rys. 11) sprzedawaną między innymi jako Micro Skate Scooter lub Razor. W 1999 roku została ona wprowadzona na rynek japoński i służyła wielu młodym Japończykom jako przenośne urządzenie transportowe. $\mathrm{Na}$ hulajnogę tę szybko przyszła światowa moda, a mniejsze jej odmiany stały się również popularnymi zabawkami dla dzieci (Micro Mobility Systems, 2020).

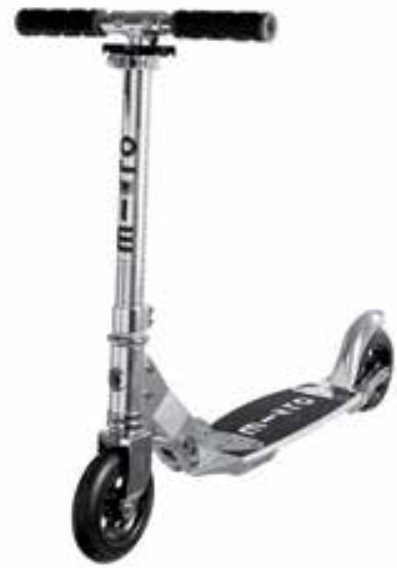

Rysunek 11. Składana hulajnoga firmy Micro Mobilty Sytems Źródło: Heim i in., 2003: 22.

Równolegle z powstaniem hulajnogi poszukiwano dla niej alternatywnego napędu. Początkowo wzorowano się na rozwiązaniach elektrycznego roweru zapoczątkowanych w 1895 roku pracami Ogdena Boltona, jednak na przeszkodzie, tak jak w przypadku roweru, stał brak odpowiednich akumulatorów. Rozwój i duża dostępność różnych napędów spalinowych jeszcze bardziej hamowały zainteresowanie elektryfikacją hulajnóg. Rezultatem było powstanie autopeda, czyli zmotoryzowanej hulajnogi, która zdobyła dużą popularność (rys. 12). Produkowano ją w Nowym Jorku od 1915 do 1921 roku. Po pierwszej wojnie światowej firma Krupp kupiła na nią licencję i wytwarzała ją w latach 1919-1922 pod nazwą Krupp-Roller. Autopedy przez pewien czas produkowały też Czechy. Zaprojektowane w 1913 roku przez Arthura Gibsona i Josepha Merkela urządzenie było wyposażone w czterosuwowy 
silnik spalinowy chłodzony powietrzem o pojemności $155 \mathrm{~cm}^{3}$ i mocy $1,5 \mathrm{KM}$. Silnik ten pozwalał hulajnodze rozpędzić się do $32 \mathrm{~km} / \mathrm{h}$. Napęd przekazywany był na przednie koło za pomocą sprzęgła tarczowego, załączanego przez wychylenie kierownicy do przodu.

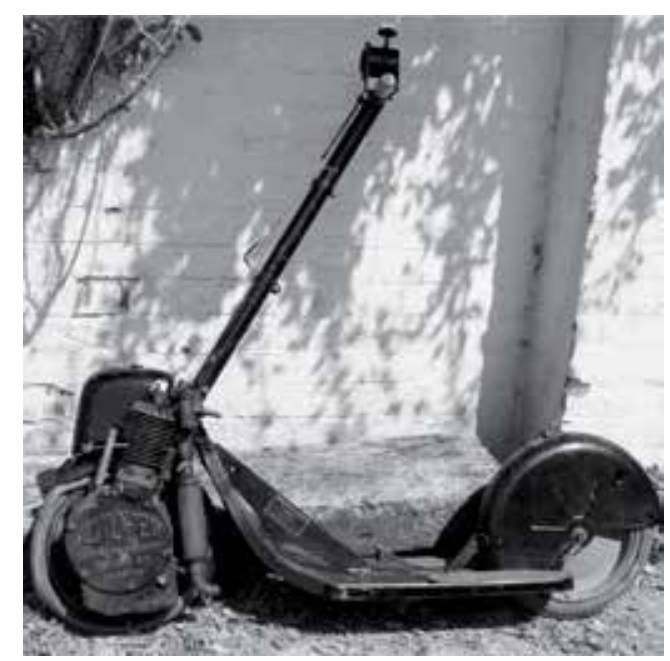

Rysunek 12. Spalinowa hulajnoga autoped

Źródło: Autoped 1916, 2020.

Pociągnięcie kierownicy do siebie pozwalało zahamować. Obracanie lewego uchwytu na kierownicy umożliwiało kontrolowanie gazu, po prawej umieszczono sterowanie dekompresatorem służącym do gaszenia silnika. Prąd do instalacji elektrycznej dostarczała sześciowoltowa prądnica. Dodatkowe wyposażenie obejmowało światła i klakson. Kierownica w tej hulajnodze była składana (zob. Autoped 1916, 2020; Autoped, 2020).

W 2001 roku na rynku pojawiła się konstrukcja nowego typu jednoosobowego pojazdu o nazwie segway. Stanowił on pierwszy dwukołowy, samobalansujący pojazd elektryczny z systemem, w którym zastosowano opatentowaną technologię stabilizacji dynamicznej. Poziom jego skomplikowania był nieporównywalny do prostoty zwykłej hulajnogi. Podobnie i wysoka cena. Niestety pojazd nie został doceniony przez użytkowników. Chociaż już w 2002 roku przewidywano sprzedaż co najmniej 50 tysięcy sztuk, to nowych właścicieli znalazło wówczas tylko 6 tysięcy pojazdów, głównie wśród policjantów, pracowników baz wojskowych, zakładów przemysłowych i magazynów. Zaprezentowana konstrukcja okazała się jednak kamieniem milowym, torującym drogę dla fali samobalansujących pojazdów takich jak hoverboardy czy unicykle (Usidus, 2020).

Jako początek ery współczesnych elektrycznych hulajnóg można uznać rok 2005. Pierwsze popularność zdobyły modele EVO Powerboards, w których producent wprowadził nowy dwubiegowy układ napędowy. 
Premiera najszybszej hulajnogi elektrycznej - NanRobot D4+ odbyła się w 2018 roku. Była ona wyposażona w dwa silniki o mocy $1000 \mathrm{~W}$ oraz akumulator litowo-jonowy $52 \mathrm{~V} 23 \mathrm{Ah}$. Taki system pozwalał osiągnąć maksymalną prędkość prawie $65 \mathrm{~km} / \mathrm{h}$ i zasięg wynoszący ponad $70 \mathrm{~km}$. Dwa tryby prędkości, eco i turbo, zapewniały dostosowanie prędkości do warunków i umiejętności kierującego (Usidus, 2020).

Obecnie elektryczne hulajnogi stały się popularną formą współdzielenia środków transportu w miastach. Są używane jako alternatywa dla jazdy na rowerze lub spacerów. Zwykle posiadają one silnik elektryczny, który umożliwia rozpędzenie się do średnio $25 \mathrm{~km} / \mathrm{h}$, zaś rzeczywisty zasięg urządzeń to od 10 do 20, a nawet $40 \mathrm{~km}$ i jest on zależny od pojemności baterii oraz warunków eksploatacji hulajnóg. Każda hulajnoga musi mieć hamulce i sygnał dźwiękowy (dzwonek), przednie i tylne światła odblaskowe, wskazane jest, aby kierowcy używali kasków.

Firmy oferujące wspólne przejazdy po raz pierwszy zaczęły udostępniać hulajnogi w dużych miastach w USA w 2018 roku. Potrzeba dostępu do transportu na krótkie odległości w wielu miastach sprawiła, że usługa przejazdu hulajnogą elektryczną staje się coraz bardziej popularna i jest sposobem na prowadzenie działalności gospodarczej.

\section{Mikrosamochód}

Mikrosamochód (ang. microcar) to termin często używany do określania samochodów o małej masie, małych gabarytach, z ograniczoną mocą jednostki napędowej i ograniczoną prędkością. Pojazdy te nie są nowością, gdyż były znane i produkowane od dawna jako konstrukcje trzykołowe lub czterokołowe, jedno- lub dwumiejscowe początkowo napędzane siłą ludzkich mięśni, później zaś silnikiem spalinowym, a współcześnie także silnikiem elektrycznym (zob. Chan, b.r.).

W licznej grupie tych pojazdów i w ich bogatej historii powstania i rozwoju można odnaleźć pewne charakterystyczne cechy i wyróżnić między innymi:

- pojazdy napędzane siłą ludzkich mięśni - z użyciem pedałów (velocars),

- pojazdy wypełniające lukę między motocyklem a samochodem (cyclecars),

- pojazdy przypominające wyglądem bąble lub pęcherze (bubble cars),

- jednomiejscowe mikropojazdy dla osób niepełnosprawnych, tzw. wózki inwalidzkie (invacars),

- mikrosamochody (voiturette),

- czterokołowce (quadricycle).

Mikrosamochody, napędzane podobnie jak rowery siłą ludzkich mięśni, rozpowszechnił po pierwszej wojnie światowej we Francji Charles Mochet. Zarówno po pierwszej, jak i drugiej wojnie światowej Europa znalazła się w kryzysie gospodarczym, samochody były bardzo drogie, a większość ludzi poruszała się rowerami lub konnymi bryczkami. 
Wynalazca przy współpracy z synem Georges'em do zbudowania mikrosamochodu napędzanego siłą mięśni wykorzystał ideę udoskonalonego wcześniej przez siebie poziomego roweru. Pomysł Mocheta polegał na zamontowaniu poziomego roweru na lekkiej ramie obudowanej sklejką i dodaniu jednego lub dwóch kół (rys. 13). Aby podwoić siłę napędową, powiększono siedzenie dla drugiej osoby i dodano kolejny zestaw pedałów. Większość rowerów w tamtym czasie była masywna i ciężka. Charles Mochet, aby obniżyć masę swojego pojazdu, zastosował ramę o przekroju rurowym i dlatego samochody na pedały jego konstrukcji były lekkie, a ich masa była zbliżona do masy zwykłego roweru. Poza tym chroniły one użytkowników przed niekorzystnymi warunkami atmosferycznymi i zapewniały miejsce dla dwóch, a nawet trzech osób. Samochody te szybko zyskały popularność, używano ich na dojazdy do pracy i na wyjazdy rekreacyjne, można było je wykorzystać jako pojazdy dostawcze, a także ciągnąć nimi lekkie przyczepy. Samochody napędzane siłą ludzkich mięśni były mało skomplikowane i przede wszystkim tanie, a ich użytkownicy często modyfikowali je we własnym zakresie, na przykład wyposażając je w silnik motocyklowy. Swoje konstrukcje również doskonalił ich pomysłodawca i producent, który na rynku mikrosamochodów istniał aż do 1958 roku (zob. People Powered Velocars, Microcars, the Wars \& the Mochets, 2014).

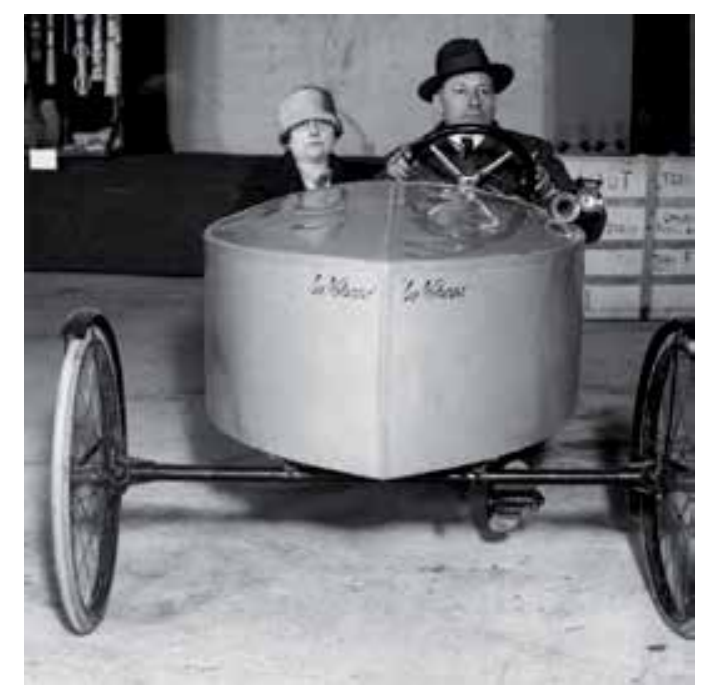

Rysunek 13. Samochód napędzany siłą ludzkich mięśni

Źródło: Velocars, 2020.

Pojazd nazywany cyclecar to rodzaj małego, lekkiego i taniego samochodu produkowanego w Europie i Stanach Zjednoczonych od roku 1910 do wczesnych lat dwudziestych XX wieku, przeważnie odkryty, trzykołowy lub czterokołowy. Wiele z nich było tak wąskich, szczególnie wcześniejsze modele, że pasażerowie siedzieli w nich nie obok siebie, lecz jak w tandemie (rys. 14). Koła tych pojazdów podobnie 
jak koła rowerów posiadały szprychy, czasami też ramiona $\mathrm{z}$ drewna. W pierwszych modelach powszechnie stosowanym układem przeniesienia napędu na tylne koła były długie skórzane pasy. Termin cyclecar został stworzony około 1912 roku przez majora Lindsaya Lloyda, członka-założyciela British Motorcycle Racing Club. Pojazdy te zapełniały na rynku lukę między motocyklem a samochodem (zob. Cyclecar, 2020; Special Features/Cyclecars, b.r.).

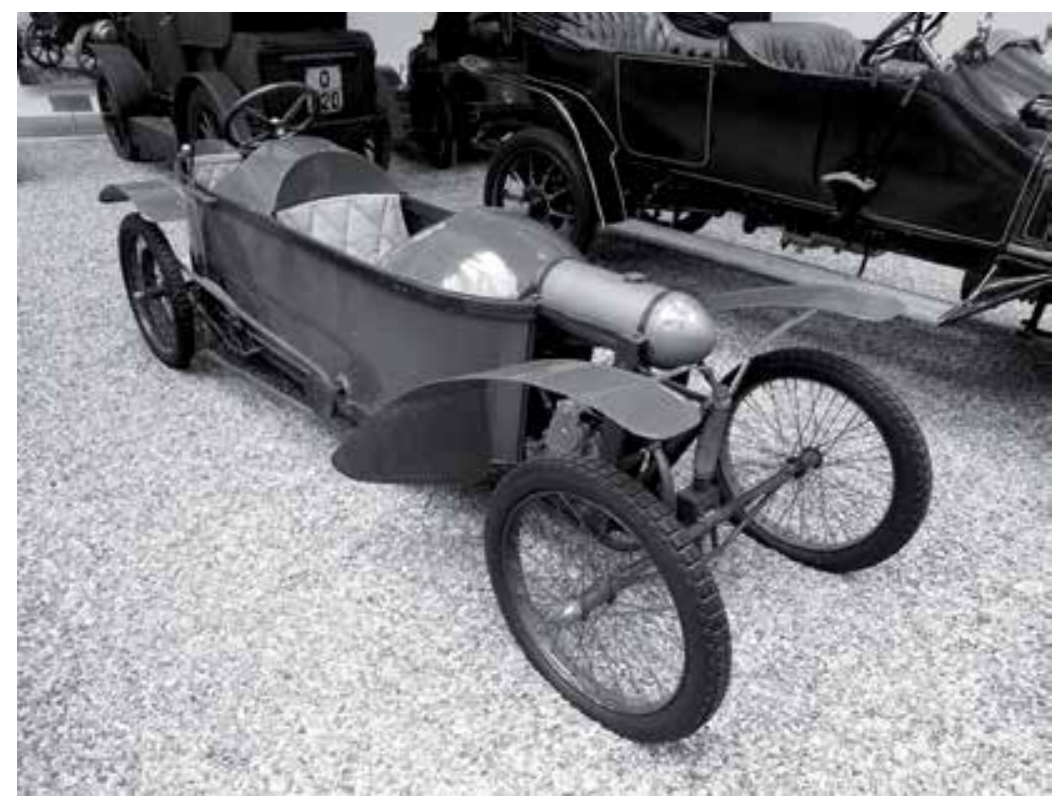

Rysunek 14. Cyclecar Bédélia BD-2 z 1912 roku

Źródło: Bédélia, 2018.

Niektóre mikrosamochody $\mathrm{z}$ lat pięćdziesiątych i sześćdziesiątych XX wieku głównie produkowane w Niemczech - nosiły przydomek „,bąbel” (bubble cars). Było to spowodowane podobnym do bąbla nadwoziem w takich pojazdach jak Messerschmitt KR175, Messerschmitt KR200 czy FMR Tg500. Podobny bąbelkowy kształt miały również mikrosamochody Isetta. Wśród niemieckich producentów samochodów typu bubble cars znajdowali się byli producenci samolotów wojskowych Messerschmitt i Heinkel. Firma BMW wyprodukowała mikrosamochód na licencji włoskiego Iso Rivolta Isetta, używając silnika z jednego $\mathrm{z}$ własnych motocykli (rys. 15). Brytyjska wersja Isetty została zbudowana tylko z jednym tylnym kołem zamiast pary kół o wąskim rozstawie, by sprostać obowiązującym w Wielkiej Brytanii przepisom dotyczącym pojazdów trójkołowych. Powstały też rodzime brytyjskie trójkołowe mikrosamochody, w tym Peel Trident (Microcar, 2020). 


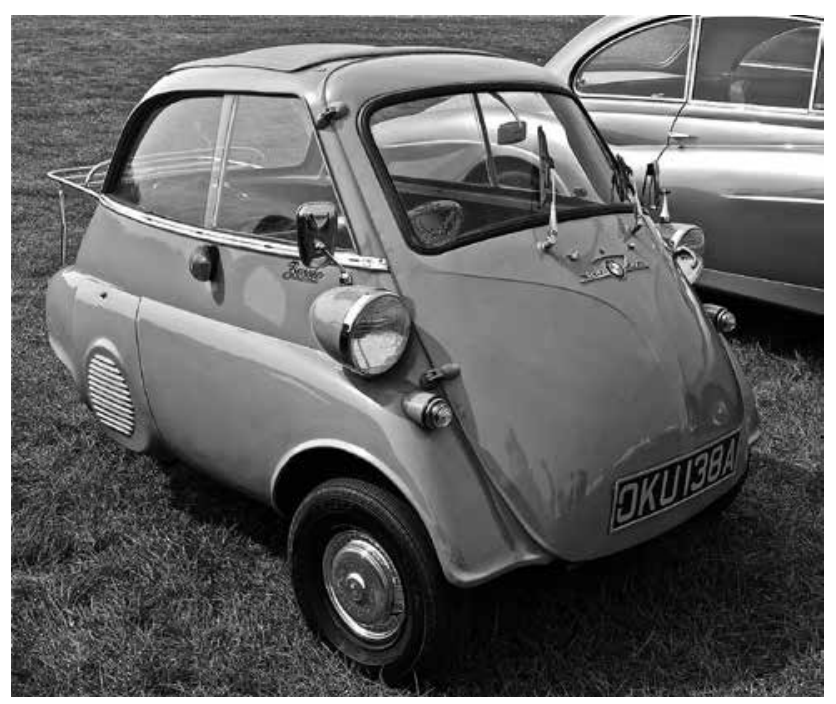

Rysunek 15. Mikrosamochód Isetta

Źródło: Isetta, 2020.

Mikropojazdy (invacars) były przeznaczone dla osób niepełnosprawnych. Wyprodukowano je głównie z myślą o żołnierzach - inwalidach drugiej wojny światowej. Brytyjskie Ministerstwo rozprowadzało te pojazdy bezpłatnie wśród osób niepełnosprawnych od 1948 do 1970 roku. Wyprodukowano ich ponad 50 modeli (rys. 16). W dniu 31 marca 2003 roku wszystkie te mikropojazdy należące do brytyjskiego rządu zostały wycofane i zezłomowane ze względów bezpieczeństwa. Pojazdy te nie spełniały współczesnych przepisów UE dotyczących homologacji (Invacar, 2020).

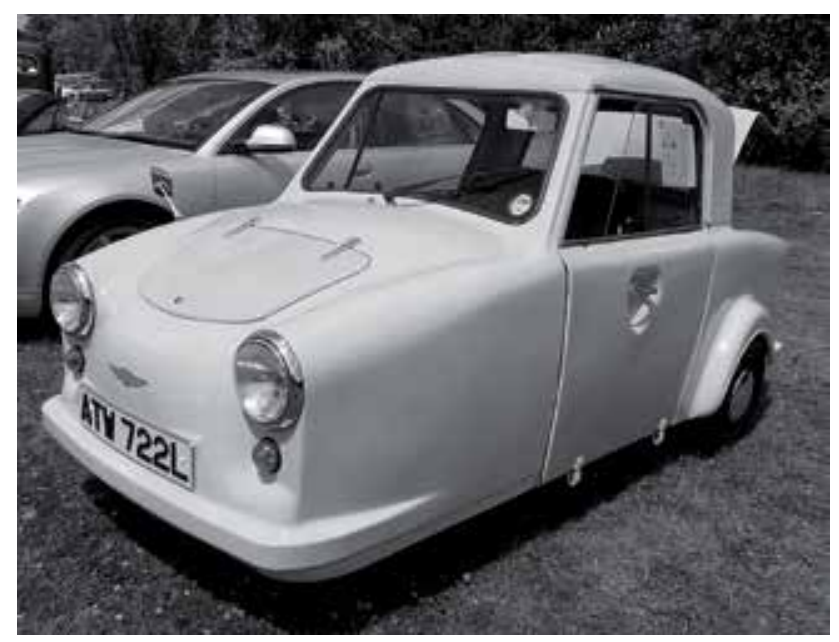

Rysunek 16. Invacar model 70

Źródło: Wikimedia Commons, $2020 \mathrm{e}$. 


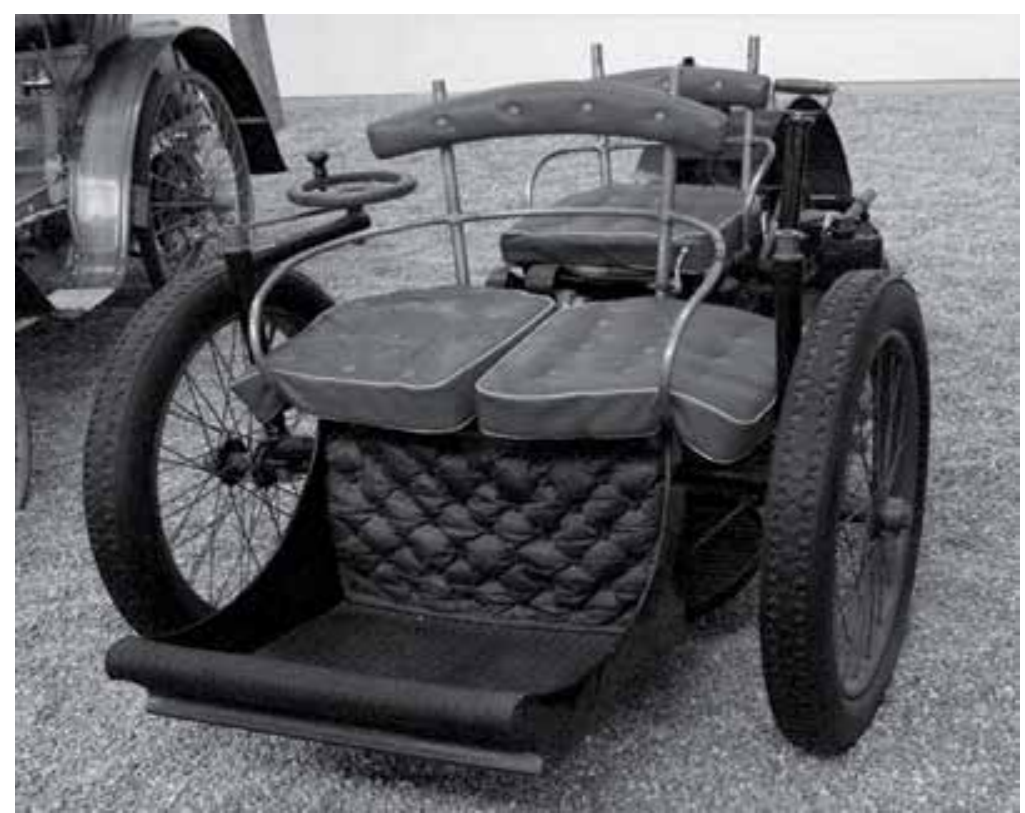

Rysunek 17. Voiturette Léona Bollée z 1895 roku

Źródło: Léon Bollée, 2019.

Mikropojazd o nazwie Voiturette to motocykl trójkołowy, który został po raz pierwszy zarejestrowany przez Léona Bollée w 1895 roku (rys. 17). Nazwa ta pochodzi od francuskiego słowa voiture określającego samochód i stała się bardzo popularna dla wielu mikrosamochodów z wczesnych lat przemysłu motoryzacyjnego. W okresie między pierwszą a drugą wojną światową były tak nazywane lekkie samochody wyścigowe z silnikami ograniczonymi do $1500 \mathrm{~cm}^{3}$, takie jak alfa romeo 158/159 alfetta lub bugatti type 13. Również po drugiej wojnie światowej produkowano małe trójkołowe pojazdy Voiturette. W latach dziewięćdziesiątych XX wieku termin voiturette we francuskiej klasyfikacji określał pojazdy o dopuszczalnej masie całkowitej $550 \mathrm{~kg}$ i własnej mniejszej niż $350 \mathrm{~kg}$. Maksymalna ich prędkość była ograniczona do $45 \mathrm{~km} / \mathrm{h}$, zaś pojemność silnika do $50 \mathrm{~cm}^{3}$ lub moc do $4 \mathrm{~kW}$ w przypadku silnika innego rodzaju, na przykład elektrycznego (Voiturette, 2020). Takie pojazdy nazywane są niekiedy motocyklami czterokołowymi lub motocyklami trójkołowymi.

W 1992 roku Unia Europejska opublikowała Dyrektywę 92/61/EWG, która orzekła, że czterokołowce należą do tej samej kategorii co motorowery. W 2002 roku Dyrektywa ramowa 2002/24/WE doprecyzowała tę definicję, wprowadzając rozróżnienie między lekkimi i ciężkimi czterokołowcami (kategorie L6e i L7e) (Dyrektywa 2002/24/WE, 2002). Od tego czasu w kilku krajach europejskich rządy klasyfikują mikrosamochody niezależnie od zwykłych samochodów, czasami stosując te same przepisy jak dla motorowerów i motocykli. Na skutek tego mikrosamochody w po- 
równaniu do samochodów mają mniej rygorystyczne wymagania dotyczące rejestracji i licencji oraz mogą podlegać niższym podatkom i kosztom ubezpieczenia.

W krajach socjalistycznych, gdzie gospodarka była planowa, ten rodzaj pojazdów również był znany. Przykładem mogą być polskie samochody Smyk, Mikrus (rys. 18) lub Gacek (zob. Dąbrowska, 2018). W odróżnieniu jednak od państw gospodarki kapitalistycznej nie przywiązywano do ich produkcji większej uwagi i nie liczono się z potrzebami rynku. Jedyną grupą społeczną, która miała większy dostęp do tego typu pojazdów byli inwalidzi.

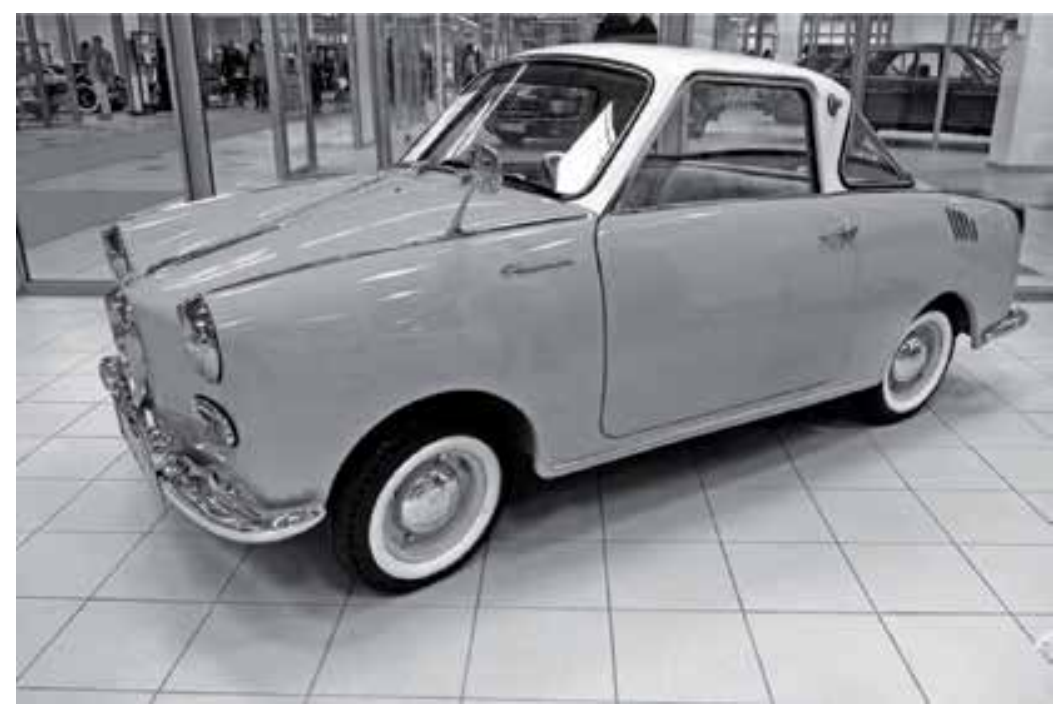

Rysunek 18. Polski mikrosamochód Mikrus

Źródło: Dąbrowska, 2018.

Obecnie samochody mikro przeżywają renesans i zaczynają cieszyć się uznaniem w krajach wysoko rozwiniętych (ze względu na ochronę środowiska, małe rozmiary, ulgi podatkowe, niskie koszty eksploatacji, możliwość prowadzenia pojazdu przez młodzież). Najbardziej popularne są jako samochody do jazdy po zatłoczonych ulicach dużych aglomeracji miejskich oraz jako drugi lub trzeci samochód w rodzinie. Wykorzystywane są także jako dostawcze, transportowe lub jako pojazdy służb miejskich. Bardzo często do prowadzenia mikrosamochodu wystarczy prawo jazdy kategorii B1, AM lub dowód osobisty (Mikrosamochód, 2019).

\section{Podsumowanie}

Mikromobilność jest ściśle powiązana z potrzebą przemieszczania się. Współcześnie postrzega się ją przede wszystkim jako współdzieloną usługę oraz korzyści, jakie może ona przynosić społeczeństwu i środowisku. Współdzielenie rowerów, hulajnóg, 
skuterów i samochodów jest nie tylko modą, lecz trwałym trendem i ostatnio popularną formą transportu w miastach.

Dyskusja o mikromobilności jest niepełna, a nawet niemożliwa bez dyskursu o jej środkach transportu i ich rozwoju, wśród których jako zasadnicze należy wymienić rowery, hulajnogi i mikrosamochody. Środki te na przestrzeni ostatnich dwóch wieków podlegały ewolucji, a ich duża rozmaitość jest rezultatem rosnącego zapotrzebowania na różnorodne formy transportu. Szczególnie duży wpływ na ewolucję mikromobilności i tym samym jej środków transportu ma elektromobilność jako konsekwencja rozpowszechniania w transporcie napędów elektrycznych.

\section{Bibliografia}

Autoped (2020), https://en.wikipedia.org/wiki/Autoped [dostęp: 10.08.2020].

Autoped 1916 (2020), Zabytkowe motocykle i rowery, http://zabytkowemotocykleirowery.pl/eveready_autoped_1918/pl [dostęp: 10.08.2020].

Bédélia (2018), https://en.wikipedia.org/wiki/Bédélia [dostęp: 10.08.2020].

Burgers E.N.R., https://burgers-enr.net/de-fietsen/modellen/ [dostęp: 13.01.2021].

Chan A. (b.r.), All About Microcars, https://carro.sg/blog/all-about-microcars/ [dostęp: 11.08.2020].

Cybermotorcycle.com, https:/cybermotorcycle.com/gallery/humber-to-1919/images/Humber-1898-Tandem-Electrique-IBra.jpg [dostęp: 6.11.2020].

Cyclecar (2020), https://en.wikipedia.org/wiki/Cyclecar [dostęp: 10.08.2020].

Dąbrowska Z. (2018), Auta PRL. Polskie mikrosamochody-Mikrus, Smyk, Gacek, Meduza, Fafik. Poznaj tajemnice polskiej motoryzacji, https://www.se.pl/ auto/porady/auta-prl-polskie-mikrosamochody-mikrus-smyk-gacek-meduza -fafik-poznaj-tajemnice-polskiej-motoryzacji-aa-P6tM-7cTG-4Pk3.html [dostęp: 11.08.2020].

Denis Johnson (inventor) (2020), https://en.wikipedia.org/wiki/Denis_Johnson_(inventor) [dostęp: 10.07.2020].

Desmond K. (2019), Electric Motorcycles and Bicycles: A History Including Scooters, Tricycles, McFarland and Company Inc., Jefferson, North Carolina.

Dyrektywa 2002/24/WE Parlamentu Europejskiego iRady zdnia 18 marca 2002 r. odnoszaca się do homologacji typu dwu- lub trzykołowych pojazdów silnikowych i uchylająca dyrektywe Rady 92/61/EWG (2002), https://eur-lex.europa.eu/LexUriServ/LexUriServ.do?uri=CONSLEG:2002L0024:20050517:EN:PDF [dostęp: 11.08.2020].

Electric bikes during the thirties (2020), http://www.ebikeportal.com/history/electric-bikes-during-the-thirties [dostęp: 15.07.2020]. 
Google.com., https://www.google.com/search?tbm=shop\&q=hulajoga $\% 20 \mathrm{~g} \% \mathrm{C} 3 \% \mathrm{~B} 3 \mathrm{r}-$ $\underline{\text { ska\&sxsrf=ACYBGNQmwzsiWJ7wh9FiZSNoh06e6vYphg:1580119207978 }}$ [dostęp: 12.08.2020].

Green Bike. Rowery elektryczne (2020), https://www.greenbike.pl/rowery-elektryczne-c-73.html [dostęp: 9.06.2020].

Heim B., Hofer M., Keibach D., Rist M., Voycheva E. (2003), Micro Mobility Systems: Realizing the scooter dream, University of St. Gallen.

Historia roweru - Pierwszy napęd i pedaty - połowa XIX w. (2020), http://wrower.pl/historia/pierwszy-naped-i-pedaly-polowa-xix-w,2057.html [dostęp: 14.05.2020].

Historia roweru (2020), Stowarzyszenie Rowerowy Toruń, http://rowerowytorun. com.pl/art/133/historia-roweru.html [dostęp: 19.07.2020].

History of ebikes (2020), http://www.ebikeportal.com/history [dostęp: 11.08.2020].

Honda Kick N Go 2 (2020), https://budgetbicyclectr.com/honda-kick-n-go-2.html [dostęp: 2.05.2020].

Hulajnoga (2020), Wynalazki i odkrycia, https://wynalazki.andrej.edu.pl/index.php/ wynalazki/21-h/1203-hulajnoga [dostęp: 10.08.2020].

Invacar (2020), https://en.wikipedia.org/wiki/Invacar [dostęp: 11.08.2020].

Isetta (2020), https://en.wikipedia.org/wiki/Isetta [dostęp: 11.08.2020].

Janczewski J. (2020), Mikromobilność w systemie transportowym miasta, „Przedsiębiorczość - Edukacja”, nr 16(1).

Léon Bollée (2019), Wikipedia, https://en.wikipedia.org/wiki/Léon_Bollée [dostęp: 6.11.2020].

Micro Mobility Systems (2020), https://en.wikipedia.org/wiki/Micro Mobility Systems [dostęp: 12.08.2020].

Microcar (2020), https://en.wikipedia.org/wiki/Microcar [dostęp: 10.08.2020].

Mikrosamochód (2019), https://pl.wikipedia.org/wiki/Mikrosamoch\%C3\%B3d [dostęp: 11.08.2020].

Mitchell N. (2015), Honda Kick 'N Go Scooter (GOGO), http://hondaroots. com/2015/01/21/honda-kick-n-go-scooter/?sfw=pass1580110663 [dostęp: 17.02.2020].

Ogden Bolton J.R. and his 1895 hub motor ebike (2020), http://www.ebikeportal.com/history/ogden-bolton-jr-and-his-1895-hub-motor-ebike [dostęp: 10.04.2020].

Penkała R. (2020), Biografie niemieckie i inne, http://www.biografie-niemieckie. $\mathrm{pl} / \mathrm{d} / 6150$-drais-von-sauerbronn-karl.html [dostęp: 10.05.2020].

People Powered - Velocars, Microcars, the Wars \& the Mochets (2014), https:// oppositelock.kinja.com/people-powered-velocars-microcars-the-wars-themo-1634063169 [dostęp: 6.11.2020].

Pinterest (2020), https://pl.pinterest.com/pin/487936940855555759/ [dostęp: 12.08.2020]. 
Rover 'Safety' bicycle, 1885, Science Museum Group, https://collection.sciencemuseumgroup.org.uk/objects/co25833/rover-safety-bicycle-1885-bicycle [dostęp: 6.11.2020].

S.H. Roper and his steam-engine powered velocipedes (2020), http://www.ebikeportal.com/history/s-h-roper-and-his-steam-engine-powered-velocipedes [dostęp: 10.08.2020].

Special Features/Cyclecars (b.r.), https://web.archive.org/web/20110622195417/ http://www.carhistory4u.com/the-last-100-years/special-features/cyclecars [dostęp: 10.08.2020].

Usidus M. (2020), Hulajnogi i pojazdy ,, hulajnogo-podobne”, https://mlodytechnik. pl/eksperymenty-i-zadania-szkolne/wynalazczosc/29936-hulajnogi-i-pojazdy-hulajnogo-podobne [dostęp: 12.08.2020].

Velocars (2020), https://tadpolerider2.wordpress.com/2015/09/16/velocars/ [dostęp: 9.08.2020].

Voiturette (2020), https://en.wikipedia.org/wiki/Voiturette [dostęp: 11.08.2020].

Wikimedia Commons (2020a), https://upload.wikimedia.org/wikipedia/commons/4/42/Draisine1817.jpg [dostęp: 13.01.2021].

Wikimedia Commons (2020b), https://upload.wikimedia.org/wikipedia/commons/6/62/Macmillan 1839.jpg [dostęp: 13.01.2021].

Wikimedia Commons (2020c), https://upload.wikimedia.org/wikipedia/commons/4/4e/Michauxjun.jpg [dostęp: 13.01.2021].

Wikimedia Commons (2020d), https://upload.wikimedia.org/wikipedia/commons/0/06/1924-71 Ladies Hobby Horse.jpg [dostęp: 6.11.2020].

Wikimedia Commons (2020e), https://upload.wikimedia.org/wikipedia/commons/6/60/Invacar 1973 (4).jpg [dostęp: 13.01.2021].

\section{Summary \\ Micromobility from the perspective of the development of bicycles, scooters and microcars. A retrospective view}

Micromobility does not have a clear definition. Sometimes it is formulated for specific conditions and its scope relates to the needs of researchers or interested institutions. Micromobility in transport has been present for a long time, although in the era of intensive automotive development in the world it was marginalized in favour of the ubiquitous car cult.

The manifestations of micromobility include slow transport devices, such as bicycles, scooters and microcars. The beginnings of such devices date back less than 200 years. Initially, they were powered by the user's muscles, and then, after the invention and improvement of drive units, they were also powered mechanically and electrically. Successive structures have been created, improved and modernized. 
The article aims to review the emergence and development of the three, in the author's opinion, most important means of transport for micromobility, namely: bicycles, scooters and microcars, and thus to justify the thesis that micromobility should be perceived not only through the prism of the service, but also from the perspective of its evolution as a means of transport.

Keywords: micromobility, bicycle, scooter, microcar 